\title{
Analisis Kemampuan Berpikir Kritis Mahasiswa Pendidikan Matematika Dalam Memecahkan Masalah Struktur Aljabar Ring Materi Daerah Integral Dan Field
}

\author{
${ }^{1}$ Clarisa, ${ }^{2}$ Fatma Liana Rahma, ${ }^{3}$ Fauziah Nur, ${ }^{4}$ Khairunnisa Hasibuan, ${ }^{5}$ Nabila Khodijah, \\ ${ }^{6}$ Siti Maysarah \\ 1,2,3,4,5,6Prodi Pendidikan Matematika, FITK, Universitas Islam Negeri Sumatera Utara, Medan- \\ Indonesia 20371 \\ Email: clarisaloverose789@gmail.com
}

\begin{abstract}
ABSTRAK
Berpikir kritis merupakan salah satu kemampuan yang sangat penting peserta didik, khususnya mahasiswa agar dapat menghubungkan persoalan atau informasi yang diperolehnya melalui penyelidikan dan penkajian secara sistematis sehingga menghasilkan ide atau solusi untuk pemecahan masalah dalam pembelajaran matematika. Penelitian ini merupakan penelitian deskriptif eksploratif dengan pendekatan kualitatif yang bertujuan menganalisis atau menggambarkan kemampuan berpikir kritis matematika mahasiswa jurusan pendidikan matematika pada materi daerah integral dan field. Indikator yang digunakan untuk menggambarkan kemampuan berpikir kritis matematika mahasiswa antara lain kemampuan identifikasi masalah, analisis, sintesis, inferensi dan evaluasi. Teknik pengumpulan data dalam penelitian ini diperoleh secara online menggunakan media google form. Instrumen yang digunakan dalam penelitian ini adalah angket tentang bagaimana pandangan mereka mengenai pemahaman materi daerah integral dan field yang terdiri dari 6 pertanyaan. Kemampuan berpikir kritis matematika mahasiswa jurusan pendidikan matematika pada mata kuliah stuktur aljabar ring materi daerah integral dan field tergolong rendah. Hal ini disebabkan karena dari uraian karakteristik kemampuan berpikir kritis matematika subjek pada masing-masing predikat diperoleh bahwa secara umum mahasiswa hanya mampu memenuhi sebagian indikator berpikir kritis atau belum mampu memenuhi seluruh indikator berpikir kritis. Faktor-faktor yang mempengaruhi kemampuan berpikir kritis matematika mahasisa pada materi daerah integral dan field tersebut antara lain : sistem pembelajaran daring yang kurang efektif, penguasaan konsep-konsep daerah integral dan field dan materi prasyarat (kemampuan awal) serta penerapannya, dan kurangnya motivasi serta minat belajar mahasiswa.
\end{abstract}

Kata kunci: Daerah integral, field

\section{ABSTRACT}

Critical thinking is one of the very important abilities of students, especially students in order to be able to connect problems or information obtained through systematic investigation and study so as to produce ideas or solutions for problem solving in learning mathematics. This research is an exploratory descriptive study with a qualitative approach that aims to analyze or describe the mathematical critical thinking skills of students majoring in mathematics education in integral and field areas. The indicators used to describe students' mathematical critical thinking skills include problem identification, analysis, synthesis, inference and evaluation skills. Data collection techniques in this study were obtained online using google form media. The instrument used in this research is a questionnaire on how they view the understanding of integral area and field material which consists of 6 questions. The ability to think critically in mathematics for students majoring in 
mathematics education in the ring algebraic structure subject for integral areas and fields is low. This is because from the description of the characteristics of the mathematical critical thinking ability of the subject in each predicate, it is found that in general students are only able to fulfill some of the critical thinking indicators or have not been able to meet all of the critical thinking indicators. Factors that influence students' critical thinking skills in mathematics in the integral and field areas include: an ineffective online learning system, mastery of integral and field concepts and prerequisite materials (initial abilities) and their application, and lack of motivation and interest. student learning.

Keywords: Integral area, field

\section{A. Pendahuluan}

Pembelajaran matematika merupakan pembelajaran yang diberikan terhadap semua jenjang pendidikan. Menurut Susanto (2013: 186), pembelajaran matematika adalah suatu proses belajar mengajar yang dibangun oleh gurubuntuk mengmabngkan kreativitas berfikir siswa yang dapat meningkatkan kemampuan berfikir siswa, serta dapat meningkatkan kemampuan mengkonstruksin pengetahuan baru sebagu upaya meningkatkan pengauasaan yang baik terhadap materi matematika.

Menurut Fisher dalam Eka Prihatini, (2016) menyatakan kemampuan berfikir kriitis sebagai kemampuan untuk menginterpretasikan, menganalisis, dan mengevaluasi ide dan argumen. Sementara itu Nugent Vitale mengatakan bahwa kemampuan berfikir kritis melibatkan tujuan, goal-direction berfikir dalam propses pembuatan keputusdan berdasarkan bukti dan bukan menebak dalam proses pemecahan maslah ilmiah. Glazer (2016: 59) menjelaskan bahwa berpikir kritis matematis memuat kemampuan dan disposisi yang dikombinasikan dengan pengetahuan awal, kemampuan penalaran matematika, dan strategi kognitif untuk mengeneralisasikan, membuktikan, mengankses situsi matematik yang tidak biasa secara reflektif. Untuk itu dengan kemampuan berfikir kritis mahasiswa dapat menganalisis serta membuat keputusan sesuai informasi yang ada.

Tujuan umum pembelajaran matematika merupakan adanya kemampuan pemecahan masalah. Pandangan pemecahan masalah sebagai proses inti dan utama dalam pemelajaran matematika bahwa pemecahan masalah mengutamakan proses dan strategi dalam menyelesaikan suatu permasalahan. pemecahan masalah matematika tidak semata-mata bertujuan untuk mencari sebuah jawaban yang benar, tetapi juga bertujuan bagaimana mengkonstruksi segala kemungkinan pemecahannya yang reasonable (layak, pantas, masuk akal) dan viabel (dapat ditampakkan). Oleh karena itu, kemampuan berpikir kritis sangat penting untuk dikembangkan sebagai bekal untuk menghadapi kompleksitas permasalahan kehidupan.

Struktur aljabar merupakan salah satu cabang matematika abstrak, yang umumnya lebih sulit dibandingkan dengan cabang matematika lain yang lebih konkret. Di dalam struktur aljabar dibicarakan tentang himpunan dengan satu operasi dan dua operasi yang berupa Grup dan Ring (Gelanggang) yang merupakan suatu aljabar modern yang standar. Struktur aljabar menurut Wahyudin (Yuniati, 2012) adalah ilmu yang mempelajari suatu himpunan dengan satu atau lebih operasi biner yang diberlakukan pada sistem aljabar tersebut. Menurut Elah (2012: 79) Mata kuliah Struktur Aljabar merupakan suatu mata kuliah yang memuat konsep-konsep yang abstrak, sehingga mahasiswa seringkali mendapat kesulitan dalam mempelajarinya.

Kemampuan berfikir kritis telah menjadi tuntutan di dalam semua pelajaran, termasuk materi daerah integral dan field. Artinya mahasiswa diharapkan dapat mengembangkan kemampuan berfikir kritisnya untuk dapat menafsirkan, menganalisis, mengevaluasi, serta membuat keputusan yang disertai dengan adanya bukti.

Atas dasar hal tersebut, peneliti tertarik melakukan penelitian yang berjudul "Analisis kemampuan Berpikir Kritis Mahasiswa Semester VI UIN Sumatera Utara Angkatan 2018 Dalam Memecahkan Masalah Struktur Aljabar Ring Materi Daerah Integral Dan Field."

\section{Kemampuan Berpikir Kritis}

Di era milenial yang penuh dengan persaingan ini, berpikir kritis mempunyai peran penting dalam menghadapi aneka macam masalah dalam kehidupan. Menurut (Sulistyorini, Yuni \&Napsiah, 2019: 279) Kemampuan berpikir kritis diperlukan untuk kesuksesan pembelajar di masa depan. Dengan demikian, para pembelajar 
sebaiknya dituntut untuk memiliki kemampuan berpikir kritis.

Kata "kemampuan" berasal dari kata mampu yang berarti kuasa (bisa, sanggup) melakukan sesuatu, dapat. Kemampuan adalah suatu kesanggupan dalam melakukan sesuatu. Seseorang dikatakan mampu apabila ia bisa melakukan sesuatu yang harus ia lakukan. Menurut Chaplin, ability (kemampuan, kecakapan, ketangkasan, bakat, kesanggupan) merupakan tenaga (daya kekuatan) untuk melakukan suatu perbuatan. Kemampuan (ability) berarti kapasitas seorang individu untuk melakukan beragam tugas dalam suatu pekerjaan. Peneliti Femi dan Syamsir (2006: 72) mengatakan bahwa Kemampuan keseluruhan seorang individu pada dasarnya terdiri atas dua kelompok faktor, yaitu:

a. Kemampuan intelektual (intellectual Ability), merupakan kemampuan yang dibutuhkan untuk melakukan berbagai aktifitas mental (berfikir, menalar dan memecahkan masalah).

b. Kemampuan fisik (Physical Ability), merupakan kemampuan melakukan tugastugas yang menuntut stamina, keterampilan, kekuatan dan karakteristik serupa.

Adapun kata kritis berasal dari bahasa yunani yaitu kritikos dan kriterion. Kata kritikos berarti pertimbangan, sedangkan kriterion mengandung makna ukuran baku atau standar. Dengan demikian secara etimologi berpikir kritis mengandung makna suatu kegiatan mental yang dilakukan seseorang untuk dapat memberi pertimbangan dengan menggunakan ukuran tertentu (Hamidah, 2018: 89).

Menurut Peter Reason menyatakan "berpikir (thingking) adalah proses mental seseorang yang lebih dari sekedar mengingat (remembering) dan memahami (comprehending). Mengingat pada dasarnya hanya melibatkan usaha penyimpanan sesuatu yang telah dialami untuk suatu saat dikeluarkan kembali atas permintaan. (Sanjaya, 2008: 230) Berpikir menyebabkan seseorang harus bergerak hingga diluar informasi yang didengarnya. Misalkan kemampuan berpikir seseorang untuk menemukan solusi baru dari suatu persoalan yang dihadapi.

Kemampuan berpikir kritis merupakan salah satu modal dasar atau modal intelektual yang sangat penting bagi setiap orang, kemampuan ini merupakan bagian yang fundamental dalam kematangan manusia. Peneliti Dwijayanti dan Yulianti (2010) mengatakan bahwa Berpikir kritis adalah berpikir secara beralasan dan reflektif dengan menekankan pembuatan keputusan tentang apa yang harus dipercayai dan dilakukan. Berpikir kritis merupakan kegiatan menganalisis ide atau gagasan ke arah yang lebih spesifik, membedakan secara tajam, memilih, mengidentifikasi, mengkaji mengembangkannya ke arah yang lebih sempurna. Proses mental ini menganalisis ide dan informasi yang diperoleh dari hasil pengamatan, pengalaman, akal sehat atau komunikasi.

Berpikir kritis adalah suatu bentuk berpikir yang digunakan dalam rangka memecahkan masalah. Berpikir kritis dalam belajar matematika merupakan suatu proses kognitif atau tindakan mental dalam usaha memperoleh pengetahuan matematika. Kemampuan berpikir kritis siswa sangat diperlukan untuk memahami dan memecahkan suatu masalah atau soal matematika yang membutuhkan penalaran, analisis, evaluasi dan interpetasi pikiran. Berpikir kritis dalam pembelajaran matematika dapat mengurangi semaksimal mungkin terjadinya kesalahan saat menyelesaikan suatu permasalahan, sehingga pada hasil akhir akan diperoleh suatu penyelesaian dengan kesimpulan yang tepat (Eny \& Masrukan, 2016: 609)

Sebagaimana telah Allah SWT firmankan dalam Al-Qur'an Surat Az-Zumar ayat 18 tentang berpikir kritis.

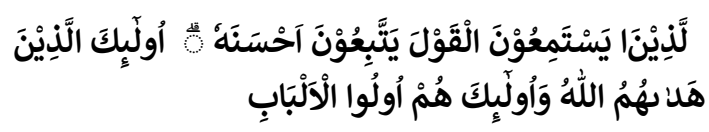

Artinya: (yaitu) mereka yang mendengarkan perkataan lalu mengikuti apa yang paling baik di antaranya. Mereka itulah orang-orang yang telah diberi petunjuk oleh Allah dan mereka itulah orang-orang yang mempunyai akal sehat.

Menurut Glaser dalam Pristasari Ajeng, (2011) indikator-indikator berpikir kritis adalah sebagai berikut:

a. Mengenal masalah

b. Menemukan cara-cara yang dapat dipakai untuk menangani masalah-masalah itu.

c. Mengumpulkan dan menyusun informasi yang diperlukan

d. Mengenal asumsi-asumsi dan nilai-nilai yang tidak dinyatakan

e. Memahami dan menggunakan bahasa yang tepat, jelas, dan khas.

f. Menganalisis data

g. Menilai fakta dan mengevaluasi pernyataanpernyataan 
h. Mengenal adanya hubungan yang logis antara masalah-masalah.

i. Menarik kesimpulan-kesimpulan dan kesamaan-kesamaan yang diperlukan.

j. Menguji kesamaan-kesamaan dan kesimpulan-kesimpulan yang seseorang ambil.

\section{Pemecahan Masalah}

Memecahkan masalah merupakan perkara yang ada dalam kehidupan sehari-hari manusia. Karena sebagian dari kehidupan manusia mempunya berbagai masalah yang berbeda-beda dan membutuhkan solusi penyelesaiannya. Apabila gagal dalam suatu penyelesaian, maka manusia akan mencari cara lain agar masalah tersebut dapat terpecahkan.

Menurut Karso (2009: 31) Pemecahan masalah adalah tipe belajar yang paling tinggi. Sesuatu itu merupakan masalah bagi siswa bila sesuatu itu baru dikenalnya, tetapi siswa telah memiliki prasyaratan hanya siswa belum tahu proses alogaritmanya (hitungan/ penyelesaiannya). Sesuatu masalah bagi siswa tetapi bukan bagi guru.

Solso dalam Zainal Abidin, (2017) berpendapat bahwa pemecahan masalah adalah berpikir atau pemikiran yang diarahkan pada pemecahan masalah spesifik yang melibatkan baik pembentukan jawaban maupun pemilihan diantara jawaban-jawaban yang mungkin. Memecahkan suatu masalah diperlukan kemampuan dalam berpikir tingkat tinggi untuk memproleh hasil yang benar.

Sedangkan menurut Evans, pemecahan masalah didefinisikan sebagai transformasi untuk menutup kesenjangan antara yang ada sekarang dengan yang akan datang. Suatu pemecahan masalah sedapat mungkin menggunakan strategi dalam prakteknya, sehingga masalah dapat dipecahkan dengan mudah. Suatu permasalahan dapat dipecahkan dengan menggunakan strategi yang dilandasi dengan konsep pengetahuan awal yang telah dimiliki agar masalah tersebut mudah untuk dipecahkan. Misalnya dalam memecahkan masalah matematika, harus mempunyai pengetahuan dasar terlebih dahulu untuk diaplikasikan ke masalah yang ingin dipecahkan.

Muijis, Daniel \& Reynold (2008: 187-190) mengemukakan bahawa Terdapat empat langkah dalam pemecahan masalah matematika, yaitu:
a. Memahami dan
mempersentasikan

1) Menemukan dengan tepat apa arti masalahnya. Ini melibatkan tindakan menemukan informasi atau mengidentifikasi masalah.

2) Perlu mengembangkan representasi yang akurat tentang masalah itu, ini membutuhkan dua pokok elemen yaitu pemahaman linguistik (siswa harus memahami kata perkata dan struktur logis kalimat-kalimat). Setelah semua kalimat di pahami, siswa harus menyatukan menjadi sebuah pengertian utuh, dan harus mampu memahami masalahnya secara keseluruhan.

b. Memilih atau merencanakan solusinya Setelah memahami masalahnya, bagian kedua proses berupa merencanakan sebuah rencana untuk menyelesaikan masalahnya.

1) Perlu memiliki sebuah strategi umum untuk memecahkan masalah, yang disebut sebuah heuristik.

2) Siswa mampu memilih sebuah Algoritma (prosedur langkah demi langkah untuk mencapai sesuatu) yang efektif untuk masing-masing bagian masalahnya.

c. Melaksanakan rencananya

Bagian ketiga melibatkan upaya menemukan solusi aktual untuk masalahnya. Bila heuristik yang dipilih di dalam langkah sebelumnya telah melahirkan rencana yang tepat dalam kaintanya dengan algoritma mana yang akan digunakan, langkah tersebut biasanya bersifat langsung dan hanya melibatkan penerapan algoritma yang dipilih saja.

d. Mengevaluasi Hasil-hasilnya

Langkah terahir adalah memeriksa jawaban. Pemeriksaan yang diketahui oleh umum tetapi sering di lupakan adalah dengan melihat apakah jawabanya masuk akal. Siwa juga perlu memeriksa bukti-bukti dan data yang mungkin kontradiktif (atau mengkonfirmasikan) jawaban mereka.

\section{Struktur Aljabar Ring}

Struktur aljabar merupakan suatu sistem matematika yang dibangun dari himpunan, operasi dan aksioma. Himpunan bilangan merupakan salah satu konsep yang dijadikan sebagai dasar pengembangan struktur aljabar lebih lanjut. Hidayah (2017: 3) menyatakan bahwa dengan menganalogikan sifat-sifat yang dimiliki oleh himpunan bilangan, beberapa struktur lain dapat ditentukan seperti Grup, ring, modul, dan lain sebagainya. 
Pembentukan struktur baru sangat ditentukan oleh pendefinisian operasi pada himpunan tersebut. Operasi penjumlahan dan perkalian "dasar" yang sudah didefinisikan dan digunakan selama ini menjadi acuan untuk pengembangan operasi lainnya yang akan dijadikan sebagai pengembangan struktur lebih lanjut. Aksioma merupakan bagian yang penting dalam pengembangan struktur aljabar, karena aksioma tersebut menjadi bagian yang akan membedakan satu struktur aljabar dengan aljabar lain.

Suatu sistem aljabar yang terdiri dari satu himpunan tak kosong dengan satu operasi biner dinamakan grup. Sistem aljabar tersebut berjumlah cukup untuk menampung strukturstruktur yang ada dalam matematika. Pada bagian ini dikembangkan suatu sistem aljabar yang terdiri dari satu himpunan tak kosong dengan dua operasi biner yang disebut dengan ring (gelanggang). Nurmala (2013: 12) menyatakan Secara eksplisit, suatu ring didefinisikan sebagai berikut:

Uniarti (2019: 8) menyatakan bahwa Struktur aljabar dengan satu himpunan objek dan dua operasi yang memenuhi aksioma-aksioma tertentu disebut Ring. Febi dalam riani (2019) menyatakan bahwa Suatu ring $(R,+, \times)$ adalah suatu himpunan tak kosong $R$ dengan dua operasi biner yaitu + sebagai operasi pertama dan $\times$ sebagai operasi kedua, yang kedua-duanya didefinisikan pada $R$ yang memenuhi aksioma sebagai berikut:

a. $(\mathrm{R},+)$ adalah grup abelian

b. Operasi $\times$ bersifat asosiatif: $(a \times b) \times c=a \times$ $(b \times c), \forall a, b, c \in R$

c. Operasi $\times$ bersifat distributif terhadap + di $R$; $\forall a, b, c \in R$

$(a+b) \times c=(a \times c)+(b \times c)$ (distributif kiri) $a \times(b+c)=(a \times b)+(a \times c)$ (distributif kanan)

\section{Daerah Integral dan Field}

a. Daerah Integral

Definisi 2.1

Suatu unsur $a \neq 0$ pada suatu ring komutatif $R$, disebut sebagai unsur pembagi nol (devisors of zero) bilamana terdapat suatu unsur $b \neq 0$ sehingga $a b=0$.

Contoh 2.1

Ring $\left\langle Z_{12},+, \cdot\right\rangle$ maka unsur-unsur $2,3,4,6$ masing-masing adalah unsur pembagi nol. Hal ini disebabkan $(2)(6)=0 ;(3)(4)=$ $0 ;(4)(3)=0 ;(6)(2)=0$

Definisi 2.2

Suatu ring komutatif $\mathrm{D}$ dengan unsur kesatuan yang tidak mempunyai unsur pembagi nol (devisors of zero) disebut sebagai daerah integral (integral domain).

Contoh 2.2

$\left\langle Z_{3},+, \cdot\right\rangle ;\left\langle Z_{5},+, \cdot\right\rangle ;\left\langle Z_{n},+, \cdot\right\rangle \quad$ dengan $n$ bilangan prima merupakan daerah integral (integral domain).

\section{Contoh 2.3}

Ring dengan bilangan bulat $\mathrm{Z}$ adalah suatu integral karena untuk setiap $x, y \in Z$, persamaan $x y=0$ dipenuhi hanya apabila $x=0$ atau $y=0$.

Teorema 2.1

Andaikan D adalah suatu daerah integral dan misalkan $a, b, c \in D$ dengan $a \neq 0$, jika $a b=a c$, maka $b=c$.

Bukti:

$$
\begin{aligned}
& a b-b c=0 \\
& a(b-c)=0 \text { karena } a \neq 0, \text { maka }(b- \\
& c)=0 \text { (integral domain) } \\
& b-c=0 \\
& b=c \text { (terbukti) }
\end{aligned}
$$

\section{b. Idempoten dan Nilpoten}

\section{Definisi 2.3}

Suatu elemen $a$ di ring $R$ disebut idempotent jika $a^{2}=a$. Suatu elemenn $a \in R$ disebut nilpotent jika $a^{n}=0$ untuk semua bilangan bulat positif $n$ (Maysarah,2020 : 30). Contoh 2.8

Carilah semua unsur idempotent dan nilpotent dari ring $\left\langle Z_{4},+, \cdot\right\rangle$

Penyelesaian:

Misalkan diambil $Z_{4}=\{0,1,2,3\} \bmod 4$

$0^{2}=0.0=0$

$1^{2}=1.1=1$

$2^{2}=2.2=0$

$3^{2}=3.3=1$

Maka unsur idempotent dari ring $\left\langle Z_{4},+, \cdot\right\rangle$ adalah 0 dan 1 . Adapun unsur nilpotent dari $\left\langle Z_{4},+, \cdot\right\rangle$ adalah 0 dan 2.

Contoh 2.10

$Z_{6}=\{0,1,2,3,4,5\}$ adalah ring terhadap operasi biner penjumlahan dan perkalian modulo 6. Maka unsur $0,1,3$, dan 4 adalah unsur idempotent, sebab:

$0^{2}=0$

$1^{2}=1$

$3^{2}=3$

$4^{2}=4$

Contoh 2.11

$Z_{8}=\{0,1,2,3,4,5,6,7\} \quad$ adalah ring terhadap penjumlahan dan perkalian modulo 
8. Maka unsur 0, 2, 4, dan 6 adalah unsur nilpoten, sebab:

$0^{2}=0$

$2^{3}=0$

$4^{2}=0$

$6^{3}=0$

\section{c. Lapangan (Field)}

Definisi 2.4

Suatu ring komutatif $f$ dengan unsur kesatuan dikatakan sebagai lapangan (field) jika setiap unsur tidak 0 (nol) adalah unsur satuan.

Penjelasan:

1) $F$ dikatakan lapangan jika $F$ sebuah gelanggang dengan unsur kesatuan, dan semua unsurnya satuan kecuali nol.

2) Lapangan (field) pasti merupakan daerah integral (integral domain). Akan tetapi, daerah integral belum tentu lapangan (field).

3) Daerah integral tidak memiliki unsur pembagi nol (devisors of zero) sehingga semua lapangan (field) pasti daerah integral.

4) Semua unsur satuan pasti tidak ada pembagi nol. Jika tidak ada pembagi nol, belum tentu semua unsur satuan.

Contoh 2.13

Buktikan bahwa $\left\langle Z_{5},+, \cdot\right\rangle$ merupakan sebuah lapangan (field)?

Penyelesaian:

Tabel 1. Cayle operasi biner perkalian $Z_{5}$

\begin{tabular}{|r|r|r|r|r|r|}
\hline$\cdot$ & 0 & 1 & 2 & 3 & 4 \\
\hline 0 & 0 & 0 & 0 & 0 & 0 \\
\hline 1 & 0 & 1 & 2 & 3 & 4 \\
\hline 2 & 0 & 2 & 4 & 1 & 3 \\
\hline 3 & 0 & 3 & 1 & 4 & 2 \\
\hline 4 & 0 & 4 & 3 & 2 & 1 \\
\hline
\end{tabular}

$\{1,2,3,4\}$ merupakan unsur satuan. Karena:

(1) $(1)=1$ sehingga $1^{-1}=1$

(2) $(3)=1$ sehingga $2^{-1}=3$

(3) $(2)=1$ sehingga $3^{-1}=2$

(4) $(4)=1$ sehingga $4^{-1}=4$

$\therefore$ dengan demikian, terbukti bahwa $\left\langle Z_{5},+, \cdot\right\rangle$ merupakan sebuah lapangan (field).

\section{Contoh 2.14}

Buktikan $Z_{p}$ dimana $p=$ prima, maka $\left\langle Z_{p},+, \cdot\right\rangle$ merupakan lapangan (field).

Penyelesaian:

$Z_{p}=\left\{0, a_{1}, a_{2}, a_{3}, \ldots a_{n}\right\} ; n \in p$

$a_{1}, a_{2}$ tidak mempunyai kelipatan. Akibatnya

$a_{1} . a_{2} \in Z_{p} \neq 0,1,2,3, \ldots$

Karena $a_{1} \cdot a_{2} \neq 0$, jika $a_{1}$ merupakan invers dari $a_{2}$

$a_{1}$ merupakan invers satuan

$a_{2}$ merupakan invers satuan

$\forall a ; a \neq 0$ merupakan unsur satuan

$\therefore Z_{p}$ merupakan sebuah lapangan (field).

\section{d. Karakteristik Dari Ring}

Definisi 2.5

Andaikan $R$ adalah suatu ring, karakteristik dari ring $R$ adalah suatu bilangan bulat positif terkecil $n$ sehingga; $n x=x+$ $x+x+\cdots+x=0$ untuk setiap $x \in R$, bila tidak terdapat bilangan $n$ yang demikian, maka $R$ mempunyai karakteristik 0 .

Teorema 2.5

Andaikan $R$ adalah suatu ring dengan unsur kesatuan 1, jika order dari unsur 1 adalah tak hingga, maka $R$ mempunyai karakteristik 0 , jika unsur 1 mempunyai order $n$, maka karakteristik dari $R$ adalah $n$.

Bukti:

Jika unsur kesatuan 1 beorder tak hingga, maka tidak terdapat bilangan bulat $n$, sehingga $R$ mempunyai karakteristik 0 .

Sekarang kita misalkan unsur kesatuan 1 beroder $n$, maka $n .1=0$, hal ini berakibat untuk setiap $x \in R$ diperoleh:

$$
\begin{aligned}
& n x=n(1 x) \\
& =1 x+1 x+\cdots+1 x \\
& =(1+1+\cdots+1) x \\
& =(n .1) x \\
& =0 x \\
& =0
\end{aligned}
$$

\section{B. Metode Penelitian}

Metode penelitian adalah cara atau jalan yang ditempuh sehubungan dengan penelitian yang dilakukan, yang memiliki langkah-langkah yang sistematis. Metode penelitian mencakup prosedur dan teknik penelitian. Metode penelitian merupakan langkah penting untuk memecahkan masalah-masalah penelitian. Dengan menguasai metode penelitian, bukan hanya dapat memecahkan berbagai masalah penelitian, namun juga dapat mengembangkan bidang keilmuan 
yang digeluti. Selain itu, memperbanyak penemuan-penemuan baru yang bermanfaat bagi masyarakat luas dan dunia pendidikan.

Metode penelitian yang digunakan yaitu penelitian deskriptif kualitatif, artinya penelitian yang menggambarkan atau mendeskripsikan objek penelitian berdasarkan fakta- fakta yang ada. Penelitian deskriptif kualitatif berusaha untuk menggambarkan semua gejala atau kondisi yang ada, yaitu keadaan gejala atau fenomena yang muncul ketika peneliti melakukan penelitian ini. Dalam penelitian ini peneliti ingin mengetahui kemampuan berpikir kritis mahasiswa pendidikan matematika mengenai daerah integral dan field yang merupakan materi dalam silabus mata kuliah struktur aljabar ring.

Subjek penelitian ini adalah Mahasiswa pendidikan matematika sebanyak 21 orang. Penelitian ini dilaksanakan dirumah masingmasing Mahasiswa pendidikan matematika sebanyak 21 orang.

Objek dari penelitian ini kemampuan berpikir kritis mahasiswa pendidikan matematika mengenai daerah integral dan field yang merupakan materi dalam silabus mata kuliah struktur aljabar ring. Teknik pengumpulan data dalam penelitian ini diperoleh secara online menggunakan media google form. Instrumen yang digunakan dalam penelitian ini adalah angket tentang kemampuan berpikir kritis mahasiswa pendidikan matematika mengenai daerah integral dan field yang merupakan materi dalam silabus mata kuliah struktur aljabar ring yang terdiri dari 6 pertanyaan. Angket ini dibuat dengan menggunakan alternatif jawaban penyataan tertutup dan terbuka.

\section{Hasil dan Pembahasan}

Dari hasil penelitian Mahasiswa Pendidikan Matematika diberikan 6 pertanyaan dan 21 tanggapan mahasiswa tentang pemecahan masalah mengenai Struktur Aljabar Ring pada materi Daerah Integral Dan Field dari hasil angket melalui google form. Hal ini bertujuan untuk mengetahui bagaimana pandangan atau cara berpikir mahasiswa dalam pemecahana masalah pendidikan matematikan mengenai struktur aljabar ring pada materi Daerah Integral Dan Field. Berikut ialah hasil dari penelitian:
Tabel 2. Data hasil penelitian

\begin{tabular}{|c|c|c|}
\hline No & Persentasi Mampu & $\begin{array}{c}\text { Persentasi Tidak } \\
\text { mampu }\end{array}$ \\
\hline 1 & $90,5 \%$ & $9,5 \%$ \\
\hline 2 & $47,6 \%$ & $42,9 \%$ \\
\hline 3 & $76,2 \%$ & $23,8 \%$ \\
\hline 4 & $28,6 \%$ & $71,4 \%$ \\
\hline 5 & $20,5 \%$ & $79,5 \%$ \\
\hline 6 & $36,5 \%$ & $63,5 \%$ \\
\hline
\end{tabular}

Dari hasil penelitian, dengan pertanyaan pertama apakah mengetahui defensi integral yang memilih Ya, dengan persentase 90,5\%. Dapat diketahui mahasiswa lebih banyak memilih Ya dikarenakan mereka setuju dengan pertanyaan yang peneliti berikan. Mereka menyetujui bahwasanya defenisi integral diketahui banyak orang. Dengan pernyataan demikian, sudah terlihat bahwasanya integral ini sudah tidak asing lagi dan sudah diketahui banyak orang.

Pertanyaan kedua tentang Manakah dari ring berikut yang menciptakan daerah integral. Hasil jawaban hampir sama, dengan persentase 47,6 \% . Dapat diketahui bahawa mengetahui ring tersebut hanya setengah, dikarenakan mereka masih ada yang belum bisa memahami ring yang menciptakan daerah integral.

Untuk pertanyaan ketiga mengenai apakah dapatmengetahui defenisi idempotein dan nipotein. Ternyata lebih dominan memilih Ya, dengan persentase $76,2 \%$. Bahwasanya sudah banyak orang yang mengetahui materi tersebut.

Pertanyaan keempat, mengenai sebutkan stu ciri-ciri suatu ring dikatakan lapangan (field), dengan persentase 28,6. Dengan pernyataan tersebut, sedikit yang mengetahui bentuk ciri-ciri suatu ring dikatakan lapangan (field) karena kebanyakan siswanya tidak mengetahui.

Selanjutnya pertanyaan kelima temukan unsur pembagi nol dari ring Z3 x Z3, dan hanya $20,95 \%$ yang hanya mengetahui jawaban dari ring Z3 x Z3. Bahwasanya banyak mahasiswa yang belum paham pada materi atau soal tersebut.

Pertanyaan keenam mengenai apakah materi daerah integral ini mudah dipahami atau tidak hanya 36,5\%yang memahami materi daerah integral ini karena menurut mereka sulit dipahami karena kurangnya literatur, dan sulit jik aberhubungan dengan contoh, dan sulit belakar materi daerah integral ini karena faktor kuliah daring. 


\section{Kesimpulan}

Berdasarkan hasil penelitian dan pembahasan yang telah diuraikan sebelumnya, dapat disimpulkan bahwa:

1. Kemampuan berpikir kritis matematika mahasiswa jurusan pendidikan matematika pada mata kuliah stuktur aljabar ring materi daerah integral dan field tergolong rendah. Hal ini disebabkan karena dari uraian karakteristik kemampuan berpikir kritis matematika subjek pada masing-masing predikat diperoleh bahwa secara umum mahasiswa hanya mampu memenuhi sebagian indikator berpikir kritis atau belum mampu memenuhi seluruh indikator berpikir kritis.

2. Berdasarkan hasil analisis, faktor-faktor yang mempengaruhi kemampuan berpikir kritis matematika mahasisa pada materi daerah integral dan field tersebut antara lain : sistem pembelajaran daring yang kurang efektif, penguasaan konsep-konsep daerah integral dan field dan materi prasyarat (kemampuan awal) serta penerapannya, dan kurangnya motivasi serta minat belajar mahasiswa.

3. Langkah-langkah yang dapat ditempuh dalam mengembangkan kemampuan berpikir kritis matematika mahasiswa antara lain meningkatkan motivasi dalam mengembangkan konsep-konsep yang telah diajarkan oleh dosen, melakukan latihanlatihan yang bersifat kontinu dalam menyelesaikan masalah-masalah yang berhubungan dengan materi tersebut, dan membaca dengan cermat permasalahan yang diberikan sehingga kemampuan dalam mengidentifikasi dan menganalisis permasalahan akan lebih baik.

\section{E. Daftar Pustaka}

Abidin, Zainal. (2017). Filsafat dan Pemecahan Masalah Matematika.

Dewi, Nurmala Rosmitha. (2019). Polinomial Atas Ring. Malang: UIN Maulana Malik Ibrahim.

Dwijananti, P. dan D. Yulianti. (2010). Jurnal pengembangan kemampuan berpikir kritis mahasiswa melalui pembelajaran Problem Based Instruction.

Hamidah, Luluk (2018). Higher Order Thinking Skills, Jawa Tengah : Desa Pustaka Indonesia.
Hidayah, Noor. (2017). Cara Mudah Memahami Struktur Aljabar. Malang: Universitas Brawijaya Press (UB Press).

Karso dkk,. (2009). Pendidikan Matematika 1, Edisi 1,Jakarta: Universitas Terbuka.

Maysarah, Siti. (2020). Struktur Aljabar Ring, Jakarta: Kencana.

Muijs, Daniel dan David Reynolds. (2008). Effective Teaching Teori dan Aplikasi, Edisi Kedua. Yogyakarta: Pustaka Pelajar, 2008.

Olivia, Femi dan Syamsir Alam. (2006). Mind Energizer, Jakarta: PT. Gramedia.

Prihartini, Eka, dkk. (2016). Meningkatkan Kemampuan Berpikir kritis Matematis Menggunakan Pendekatan Open Ended, Seminar Prosiding UNNES.

Pritasari, Ajeng Desi Crisandi. (2011). Upaya Meningkatkan Kemampuan Berpikir Kritis Siswa pada Pembelajaran Matematika (Penenlitian Tindakan Kelas di Kelas XI IPA 2 Sekolah Menengah Atas Negeri 8 Yogyakarta) Melalui Pembelajaran Kooperatif Tipe Group Investigation (GI), Skripsi, Yogyakarta; Universitas Negeri Yogyakarta.

Rachman, Febi Riani, dkk. Ideal Pada Ring Komutatif, Jurnal Matematika UNAND, Vol. 7, No. 2

Suci, Yuniati. (2012). Pengembangan Bahan Ajar Struktuir Aljabar Berbasis Tugas Tesitasi Untuk Mahasiswa Universitas Islam Negeri Suska Riau, Gamatika, Vol. 3, No. 1 .

Sulistiani, Eny dan Masrukan. (2016). Pentingnya Berpikir Ktitis Dalam Pembelajaran Matematika Untuk Menghadapi Tantangan MEA. Semarang: Universitas Negeri Semarang.

Sulistyorini, Yuni dan Siti Napfiah. (2019). 
Analisis Kemampuan Berpikir Kritis Mahasiswa Dalam Memecahkan Masalah Kalkulus, Jurnal Program Studi Pendidikan Matematika, Vol. 8, No. 2.

Susanto, Ahmad. (2013). Teori Bilangan dan Pembelajaran Di Sekolah Dasar. Jakarta: Kencana Perenada Media Group.

Sanjaya, Wina. (2008). Strategi Pembelajaran, Jakarta; kencana.

Uniarti, Annisa. (2019). Suatu Kajian Tentang Jumlahan Langsung Pada Ring. Makasar: Universitas Negeri Makassar. 